\title{
Hyperdense middle and anterior cerebral arteries: familiar and not so familiar CT signs of acute ischaemic stroke
}

\author{
Mark A Rodrigues, ${ }^{1}$ Constantinos A Parisinos ${ }^{2}$ \\ ${ }^{1}$ Department of Radiology, Western General Hospital, Edinburgh, Midlothian, UK \\ ${ }^{2}$ Department of Acute Medicine, Royal Free Hospital, London, UK
}

Correspondence to Dr Constantinos A Parisinos, c.a.parisinos@gmail.com

\section{DESCRIPTION}

We present a case of a 67-year-old patient who attended accident and emergency with left-sided weakness. Background included atrial fibrillation (on long-term warfarin). Examination revealed left hemiparesis, expressive dysphasia and a reduced Glasgow Coma Score, consistent with a right hemisphere cerebral vascular accident.

Initial CT head demonstrated a hyperdense right middle cerebral artery (MCA) with extensive right MCA territory infarct and minor mass effect (figure 1). The left anterior cerebral artery (ACA) was also hyperdense, with loss of grey/white matter differentiation within the left ACA vascular territory, suggestive of a further infarct (figure 2).

The patient was managed conservatively but unfortunately following further deterioration a repeat CT showed

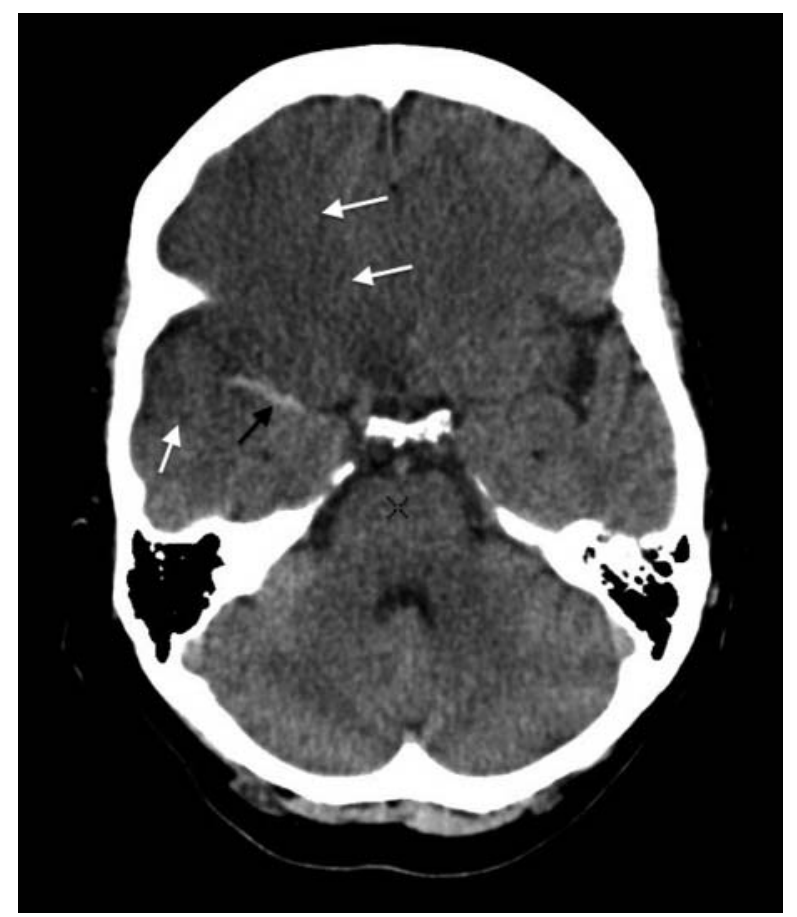

Figure 1 Non-contrast-enhanced axial CT image showing a hyperdense right middle cerebral artery (MCA) (black arrow), with loss of grey-white matter differentiation and sulcal effacement in the associated vascular territory (white arrow), consistent with an ischaemic right MCA infarct. haemorrhagic transformation of the right MCA territory infarct with significant mass effect and transtentorial herniation. There was an evolution of the left ACA territory infarct (figure 3).

Neurosurgical intervention was not deemed appropriate and the patient died later that day due to raised intracranial pressure secondary to significant mass effect.

The hyperdense MCA sign represents occlusive thrombus within an MCA. It is one of the most well-recognised early signs of ischaemic stroke detectable on non-contrast $\mathrm{CT}^{1}$ and is associated with a poor prognosis. ${ }^{2}$ In contrast, a hyperdense ACA is a less well-recognised sign. This probably relates to the preferential course of emboli into the MCA rather than the ACA and the smaller calibre of the ACA, making detection of occlusive ACA emboli on

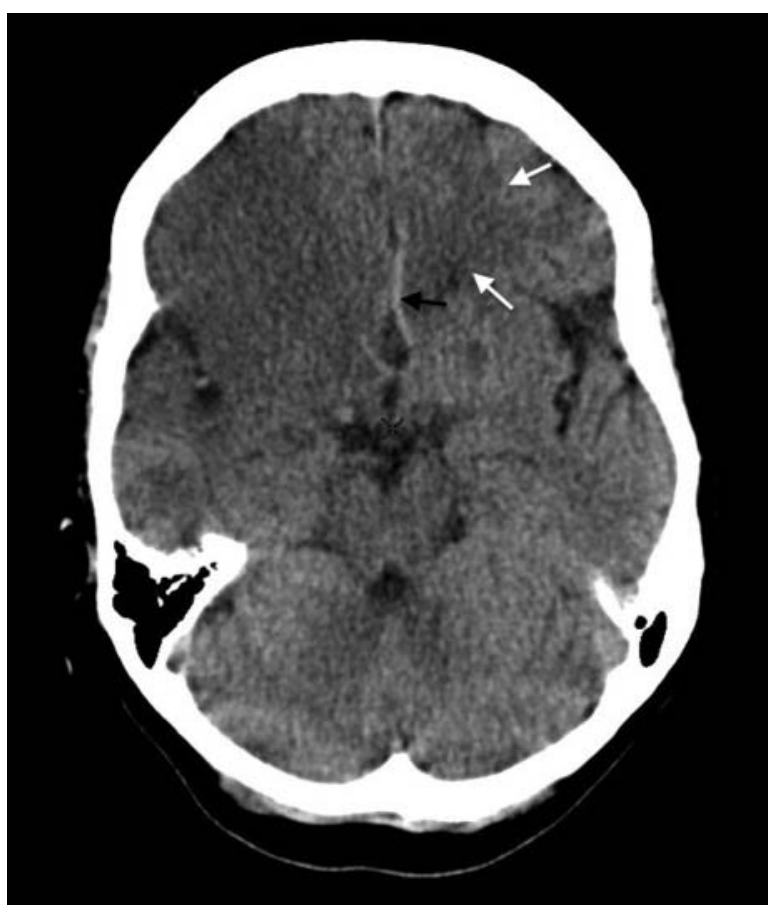

Figure 2 Non-contrast-enhanced axial CT image showing a hyperdense left anterior cerebral artery (ACA) (black arrow) with subtle loss of grey-white matter differentiation in the associated vascular territory (white arrow). These findings are suggestive of a synchronous ischaemic left ACA infarct. 


\section{BMJ Case Reports}

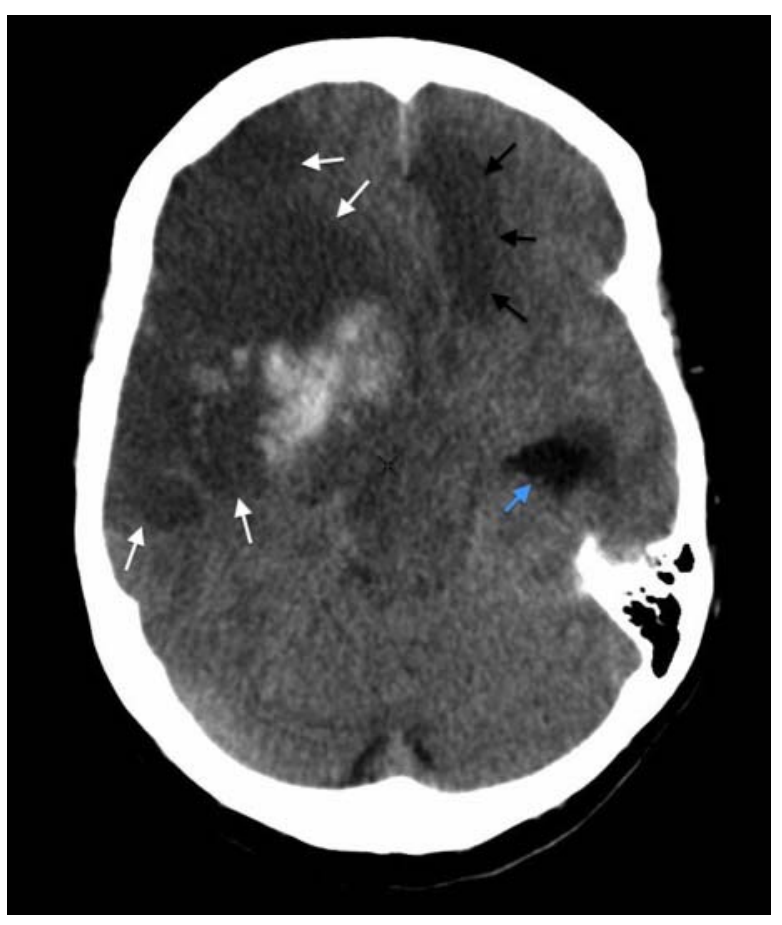

Figure 3 Non-contrast-enhanced axial CT image showing evolution of both the left anterior cerebral artery (black arrow) and right middle cerebral artery (white arrow) ischaemic infarcts. High attenuation within the right frontal lobe and basal ganglia is consistent with an intraparenchymal haemorrhage. There is resultant mass effect from this and the associated vasogenic oedema, with midline shift and evidence of obstructive hydrocephalus of the left lateral ventricle, signified on this image by the dilated temporal horn of the left lateral ventricle (blue arrow).
CT more challenging. It, however, remains an important early sign of ACA territory ischaemic infarction, although its relation with prognosis is currently unclear. ${ }^{3}$

Learning points

- The hyperdense middle cerebral artery sign is a familiar early CT finding in ischaemic stroke and predicts a poor clinical outcome.

- In contrast, the hyperdense anterior cerebral artery (ACA) sign is a less well recognised, but nonetheless useful, early CT sign for ischaemic ACA infarcts; however, its relationship with prognosis is not fully understood.

Competing interests None.

Patient consent Obtained.

\section{REFERENCES}

1. Barber PA, Demchuk AM, Hudon ME, et al. Hyperdense sylvian fissure MCA "dot" sign: A CT marker of acute ischemia. Stroke 2001:32:84-8.

2. Manelfe C, Larrue V, von Kummer R, et al. Association of hyperdense middle cerebral artery sign with clinical outcome in patients treated with tissue plasminogen activator. Stroke 1999;30:769-72.

3. Jensen UR, Weiss M, Zimmerman P, et al. The hyperdense anterior cerebral artery sign (HACAS) as a computed tomography marker for acute ischemia in the anterior cerebral artery territory. Cerebrovasc Dis 2010;29:62-7. 


\section{BMJ Case Reports}

Copyright 2012 BMJ Publishing Group. All rights reserved. For permission to reuse any of this content visit http://group.bmi.com/group/rights-licensing/permissions.

BMJ Case Report Fellows may re-use this article for personal use and teaching without any further permission.

Please cite this article as follows (you will need to access the article online to obtain the date of publication).

Rodrigues MA, Parisinos CA. Hyperdense middle and anterior cerebral arteries: familiar and not so familiar CT signs of acute ischaemic stroke. BMJ Case Reports 2012;10.1136/bcr-2012-006915, Published XXX

Become a Fellow of BMJ Case Reports today and you can:

- Submit as many cases as you like

- Enjoy fast sympathetic peer review and rapid publication of accepted articles

Access all the published articles

- Re-use any of the published material for personal use and teaching without further permission

For information on Institutional Fellowships contact consortiasales@bmjgroup.com

Visit casereports.bmj.com for more articles like this and to become a Fellow 